\title{
INTERPRETASI EKG NORMAL PRAKTIS BAGI PEMULA: SUATU TINJAUAN MINI
}

\section{Sidhi Laksono}

Fakultas Kedokteran Universitas Muhammadiyah Prof Dr Hamka, Banten, Indonesia Email: sidhilaksono@uhamka.ac.id

\begin{tabular}{|c|c|c|}
\hline $\begin{array}{c}\text { Tanggal Submisi } \\
\text { 20 Juli 2021 }\end{array}$ & $\begin{array}{c}\text { Tanggal Penerimaan } \\
\text { 24 November 2021 }\end{array}$ & Tanggal Publish \\
25 Desember 2021 \\
\hline
\end{tabular}

\begin{abstract}
ABSTRAK
Pemeriksaan elektrokardiogram (EKG) merupakan uji diagnostik untuk melihat gambaran aktivitas elektrik dari listrik jantung, sehingga dapat diketahui gangguan listrik jantung atau aritmia. EKG ini rutin dilakukan untuk melihat gangguan listrik jantung, sehingga diperlukan kemampuan praktisi medis dalam membaca interpretasinya. Secara praktis, EKG dapat dibaca melalui 8 tahapan mulai dari menentukan irama sinus hingga morfologi gelombang T. Dari tinjauan mini ini akan dibahas secara ringkas dan praktis dalam menginterpretasikan EKG bagi praktisi medis.
\end{abstract}

Kata kunci: EKG; interpretasi praktis; praktisi medis

\section{ABSTRACT}

Electrocardiogram (ECG) examination is a diagnostic test to se a picture of the electrical activity of the heart, so that electrical disturbances or arrhythmias can be identified. This ECG is routinely performed to see electrical disturbances in the heart, so it requires the ability of medical practitioners to read its interpretation. Practically, the ECG can be read through 8 stages from determining sinus rhythm to $T$ wave morphology. From this mini review, we will briefly and practically discuss the interpretation of the ECG for medical practitioners.

Keywords: ECG; practical interpretation; medical practice

\section{PENDAHULUAN}

Elektrokardiogram merupakan suatu grafik yang menggambarkan aktivitas dari kelistrikan jantung yang berasal dari sadapan-sadapan yang terpasang pada tubuh (Sampson \& McGrath, 2015a). Pemeriksaan EKG ini merupakan pemeriksaan yang diharapkan dapat membantu penegakan diagnosis yang akan dilakukan oleh 
dokter, sehingga alat EKG ini hanyalah sebagai alat bantu dan hasil yang didapatkan harus disesuaikan dengan kondisi klinis (Jones., 2016). Hasil abnormal dari rekaman EKG tidak selalu mengindikasikan adanya kelainan pada jantung, begitupun sebaliknya hasil normal dari rekaman EKG belum tentu jantung penderita normal (Harris, 2016).

Oleh karena itu, diperlukan kemampuan praktisi medis untuk dapat membaca EKG secara praktis. Pembacaan secara praktis untuk pemula bisa dilakukan dengan menentukan irama sinus, frekuensi denyut jantung, aksis jantung, morfologi gelombang $P$, interval PR, kompleks QRS, segmen ST dan gelombang T (Khan, 2004). Dalam tinjauan mini ini akan dibahas secara ringkas mengenai pembacaan EKG secara ringkas dan praktis bagi praktisi medis.

\section{EKG}

Mesin EKG konvensional terdiri dari 12 sadapan, yang dibagi menjadi dua kelompok, yaitu sadapan ekstremitas dan sadapan prekordial. Sadapan ekstremitas selanjutnya dikategorikan sebagai sadapan ekstremitas bipolar standar I, II dan III, dan sadapan unipolar augmented aVL, aVF, dan aVR. Sadapan prekordial termasuk V1 hingga V6. Sadapan ekstremitas melihat jantung dalam bidang vertikal, dan sadapan prekordial merekam aktivitas listrik jantung dalam bidang horizontal (Kligfield et al., 2007).

EKG mewakili rekaman grafis dari aktivitas jantung listrik yang ditelusuri pada kertas elektrokardiograf. Prinsip dasar di balik perekaman EKG adalah gaya elektromagnetik, arus atau vektor yang memiliki besar dan arah. Ketika arus depolarisasi berjalan menuju elektroda, ia dicatat sebagai defleksi positif, dan ketika bergerak menjauh dari elektroda, ia muncul sebagai defleksi negatif (Wasserlauf et al., 2019). Penelusuran EKG khas dari detak jantung normal (atau siklus jantung) terdiri dari gelombang $\mathrm{P}$, kompleks QRS, dan gelombang T. Tegangan dasar elektrokardiogram dikenal sebagai garis isoelektrik. Biasanya garis isoelektrik diukur sebagai bagian dari tracing mengikuti gelombang $\mathrm{T}$ dan sebelum gelombang $\mathrm{P}$ berikutnya (Benade, S.A.;Bombale, 2016).

\section{EKG SEBAGAI VOLTMETER}

EKG mengukur sejumlah kecil tegangan yang dihasilkan oleh depolarisasi otot jantung. Pada sumbu vertikal, atau sumbu $y$, pada EKG adalah tegangan, dengan setiap milimeter (mm) kertas sama hingga 0,1 milivolt (mV) (Chamley et al., 2019). Untuk tujuan praktis, kita sering mengacu pada amplitudo, atau tinggi, 
kompleks EKG dalam milimeter kertas, bukan dalam milivolt. Pada awal atau akhir EKG, Anda mungkin melihat gelombang persegi, yang diinduksi mesin, yaitu tinggi $10 \mathrm{~mm}$; ini adalah arus 1-mV yang dimasukkan oleh mesin untuk kalibrasi. Keuntungannya bisa diubah sehingga kompleks tegangan tinggi muat di atas kertas, atau agar tegangan rendah kompleks diperbesar. Mengubah gain jarang terjadi, tetapi akan terlihat jelas dari penanda kalibrasi (Taylor., 2006).

\section{MENENTUKAN IRAMA SINUS}

Ketika membaca hasil EKG yang harus kita tentukan terlebih dahulu adalah irama jantung, iramanya sinus atau tidak (Kusumoto, 2020). Irama sinus ditandai dengan adanya gelompang $\mathrm{P}$ diikuti dengan kompleks QRS, pada lead II gelombang p (+) dan pada lead aVR gelombang $P(-)$, jarak antara R ke R selanjutnya (interval RR') regular, dan dengan laju 60100x/menit. Jika laju QRS <60x/menit disebut sinus bradikardia dan jika laju QRS >100x/menit disebut sinus takikardia (Bacharova et al., 2010).

\section{MENENTUKAN FREKUENSI DENYUT JANTUNG}

Setelah kita mendapatkan irama dari jantung yang harus kita lakukan selanjutnya adalah menentukan frekuensi denyut jantung. Terdapat beberapa cara untuk mendapatkan hasil frekuensi denyut jantung (Bacharova et al., 2010) yaitu:

1. Tiga ratus dibagi jumlah kotak besar pada interval R-R';

2. Seribu lima ratus dibagi jumlah kotak kecil pada interval R-R' ;

3. Jika interval R-R' irregular, maka hitung jumlah kompleks QRS dalam 6 detik (30 kotak besar, kemudian dikalikan 10).

\section{MENENTUKAN AKSIS JANTUNG}

Aksis bertujuan menggambarkan posisi jntung itu sendiri. Untuk menentukan aksis kita dapat melihat gambaran defleksi kompleks QRS pada lead I dan lead aVF (Kozłowski, 2018). Defleksi kompleks QRS didapatkan dari rata-rata kompleks QRS terhadap garis isoelektrik, jika defleksi positif maka rata-rata kompleks QRS berada di atas garis isoelektrik $(\mathrm{R}>\mathrm{S}+\mathrm{Q})$ dan jika defleksi negatif maka rata-rata kompleks QRS berada di bawah garis isoelektrik $(\mathrm{R}<\mathrm{S}+\mathrm{Q})$. Terdapat 4 kemungkinan dalam menginterpretasikan aksis (Morris, 2002), yaitu:

1. Normal, pada lead I didapatkan defleksi (+) dan pada lead aVF didapatkan defleksi (+);

2. Left Axis Deviation (LAD), pada lead I didapatkan defleksi (+) dan 
pada lead aVF didapatkan defleksi

$(-)$

3. Right Axis Deviation (RAD), pada lead I didapatkan defleksi (-) dan pada lead aVF didapatkan defleksi $(+)$;

4. Extreme Axis Deviation (EAD), pada lead I didapatkan defleksi (-) dan pada lead aVF didapatkan defleksi (-).

\section{GELOMBANG P}

Gelombang P merupakan gelombang pertama siklus jantung, dan menunjukkan depolarisasi atrium. Setengah gelombang $\mathrm{P}$ pertama terjadi karena stimulasi atrium kanan serta bentuk downslope berikutnya terjadi karena stimulasi atrium kiri (Sampson \& McGrath, 2015). Terdapat beberapa karakteristik gelombang $\mathrm{P}$ yang normal, yaitu gelombang lembut dan tidak tajam, durasi normal $0,08-0,10$ detik (2-2,5 kotak kecil), dan tinggi tidak lebih dari 2,5 mm (Goldberger; \& Kin, 2013). Adapun morfologi dari gelombang $\mathrm{P}$ yang berbeda dari yang normal (gelombang $\mathrm{P}$ abnormal), yaitu gelombang $\mathrm{P}$ pulmonal (tinggi $>2,5$ $\mathrm{mm}$ ), gelombang $\mathrm{P}$ mitral (lebar > 2,5 kotak kecil/ > 0,10 detik), gelombang $\mathrm{P}$ bifasik (Morris, 2002).

\section{INTERVAL PR}

Interval PR menunjukan waktu yang diperlukan gelombang depolarisasi untuk bergerak dari atrium ke ventrikel. Nilai normal dari interval PR adalah 0,12-0,2 detik (3-5 kotak kecil). Interval PR yang memanjang >5 kotak kecil, terdapat dalam keadaan AV blok. Interval PR yang memendek <3 kotak kecil, terdapat dalam keadaan wolf Parkinson white syndrome (Cossey; \& Wheeler, 2003).

\section{KOMPLEKS QRS}

Kompleks QRS menunjukan depolarisasi ventrikel yang secara bersamaan dengan atrium repolarisasi. Kompleks QRS dikatan sempit jika memiliki lebar/durasi $0,08-0,10$ detik (2 - 2,5 kotak kecil). Gelombang Q merupakan defleksi negatif pertama, gelombang $\mathrm{R}$ merupakan defleksi positif pertama, dan gelombang $\mathrm{S}$ merupakan defleksi negatif setelah defleksi positif (gelombang R) (Cossey; \& Wheeler, 2003).

\section{SEGMEN ST}

Segmen ST merupakan saat ventrikel berkontraksi dan mengosongkan isinya. Terdapat titik pertemuan antara akhir dari kompleks QRS dan awal segmen ST yang disebut $J$ point, segmen ST dikatakan normal jika $J$ point berada sejajar dengan garis 
isoelektrik (Carey et al., 2014). Jika J point berada di bawah garis isoelektrik disebut ST depresi dan jika $J$ point berada di atas garis isoelektrik disebut ST elevasi. (Tso et al., 2015). Segmen ST biasanya isoelektrik, dan gelombang $\mathrm{T}$ di sebagian besar sadapan adalah defleksi tegak dari amplitudo dan durasi variabel (Price et al., 2010).

\section{GELOMBANG T}

Gelombang $\mathrm{T}$ menunjukan repolarisasi ventrikel. Gelombang $\mathrm{T}$ normal jika tinggi kurang dari $5 \mathrm{~mm}$ pada sadapan ekstremitas dan jika tinggi kurang dari $10 \mathrm{~mm}$ pada sadapan prekordial. Jika terdapat gelombang $\mathrm{T}$ terbalik yang lebar dan dalam maka adanya iskemia dan jika terdapat gelombang $\mathrm{T}$ yang sangat tinggi maka adanya hiperkalemia/hipokalemia (Tso et al., 2015).

\section{INTERVAL QT}

Interval ini mewakili semua awal depolarisasi hingga akhir repolarisasi ventrikel. Durasi interval QT normal agak kontroversial, dan berbagai durasi normal telah disarankan sebelumnya. Secara umum, interval QT normal adalah kurang dari 400 hingga 440 milidetik (ms), atau 0,4 hingga 0,44 detik. Wanita biasanya memiliki interval QT yang sedikit lebih lama daripada pria. Interval QT memiliki hubungan terbalik dengan denyut jantung. Interval QT yang memanjang menimbulkan risiko segera untuk terjadinya aritmia ventrikel yang serius, termasuk Torsades de Pointes, takikardia ventrikel, dan fibrilasi ventrikel (Sattar \& Lovely, 2021).

\section{KESIMPULAN}

EKG menggambarkan irama jantung dan memberikan gambaran gangguan kelistrikan janutng, dimana dapat dibaca secara praktis dengan melihat jenis irama, frekuensi denyut nadi, aksis jantung, morfologi gelombang $\mathrm{P}$, interval $\mathrm{PR}$, kompleks QRS, segmen ST dan gelombang T.

\section{REFERENSI}

Bacharova, L., Bang, L., \& Wagner, G. S. (2010). Basic understanding and clinical application of the electrocardiogram: Past, present, and future. Journal of Electrocardiology, 43(3), 183-186. https://doi.org/10.1016/j.jelectrocar d.2010.03.005

Benade, S.A.;Bombale, U. L. (2016). Finger Touch Based Ecg Monitoring. International Journal of Research in Engineering and Technology, 05(07), 263-266. https://doi.org/10.15623/ijret.2016. 0507040

Carey, B. M. G., Al-zaiti, S. S., Kozik, T. M., \& Pelter, M. (2014). Interpretation Questions : Answers : 23(5), 429-431.

Chamley, R. R., Holdsworth, D. A., Rajappan, K., \& Nicol, E. D. 
(2019). ECG interpretation. European Heart Journal, 40(32), 2663-2666.

https://doi.org/10.1093/eurheartj/eh z559

Cossey;, B. H., \& Wheeler, R. M. (2003). Home Program. AORN Journal, 78(4). http://linkinghub.elsevier.com/retri eve/pii/S0001209206626446

Goldberger; A. L. G. Z. D. . A. S., \& Kin. (2013). Goldberger's Clinical Electrocardiography-A Simplified Approach. Elsevier Inc.

Harris, P. R. E. (2016). The Normal Electrocardiogram: Resting 12Lead and Electrocardiogram Monitoring in the Hospital. Critical Care Nursing Clinics of North America, 28(3), 281-296. https://doi.org/10.1016/j.cnc.2016. 04.002

Jones., S. A. (2016). ECG Notes Interpretation and Management Guide. (Third Edit). E.A. Davis Company.

Khan, E. (2004). Clinical skills: the physiological basis and interpretation of the ECG. British Journal of Nursing (Mark Allen Publishing), 13(8), 440-446. https://doi.org/10.12968/bjon.2004. 13.8.12778

Kligfield, P., Gettes, L. S., Bailey, J. J., Childers, R., Deal, B. J., Hancock, E. W., van Herpen, G., Kors, J. A., Macfarlane, P., Mirvis, D. M., Pahlm, O., Rautaharju, P., \& Wagner, G. S. (2007). Recommendations for the Standardization and Interpretation of the Electrocardiogram. Part I: The Electrocardiogram and Its Technology A Scientific Statement From the American Heart Association Electrocardiography and Arrhythmias Committee,
Council on Clin. Journal of the American College of Cardiology, 49(10), 1109-1127. https://doi.org/10.1016/j.jacc.2007. 01.024

Kozłowski, D. (2018). Method in the Chaos - a step-by-step approach to ECG Interpretation. European Journal of Translational and Clinical Medicine, 1(1), 74-87. https://doi.org/10.31373/ejtcm/922 55

Kusumoto, F. (2020). ECG Interpretation. In $A n$ Aid to Electrocardiogram. https://doi.org/10.5005/jp/books/12 362_2

Morris, S. M. (2002). ABC of Clinical electrocardiography. Introduction. II-Basic terminology. BMJ. https://doi.org/10.1093/bja/aep208

Price, D., Cardiologist, C., Mary, S., \& Wight, I. (2010). How to read an electrocardiogram (ECG). Part 1: Basic principles of the ECG. The normal ECG. South Sudan Medical Journal, 3(2), 26-31.

Sampson, M., \& McGrath, A. (2015a). Understanding the ECG. Part 1: Anatomy and physiology. British Journal of Cardiac Nursing, 10(11), 548-554. https://doi.org/10.12968/bjca.2015. 10.11 .548

Sampson, M., \& McGrath, A. (2015b). Understanding the ECG Part 2: ECG basics. British Journal of Cardiac Nursing, 10(12), 588-594. https://doi.org/10.12968/bjca.2015. 10.12 .588

Sattar, Y., \& Lovely. (2021). Electrocardiogram. StatPearls(Internet).

Taylor., G. J. (2006). 150 Practice ECGs: Interpretation and Review. 
Third Edition. (Third Edit). Blackwell Publishing Asia.

Tso, C., Currie, G. M., Gilmore, D., \& Kiat, H. (2015). Electrocardiography: A technologist's guide to interpretation. Journal of Nuclear Medicine Technology, 43(4), 247252.

https://doi.org/10.2967/jnmt.115.1 63501

Wasserlauf, J., You, C., Patel, R., Valys, A., Albert, D., \& Passman, R. (2019). Smartwatch Performance for the Detection and Quantification of Atrial Fibrillation. Circulation: Arrhythmia and Electrophysiology, 12(6), $1-9$. https://doi.org/10.1161/CIRCEP.11 8.006834 